\title{
Profitability and Value Chain Assessment of Groundnut in Digga District of East Wollega Zone, Oromia National Regional State, Ethiopia
}

\author{
Oliyad Sori ${ }^{1, *}$, Hika Wana ${ }^{2}$ \\ ${ }^{1}$ Department of Agribusiness and Value Chain Management, Wollega University, Shambu, Ethiopia \\ ${ }^{2}$ Department of Agricultural Economics, Wollega University, Shambu, Ethiopia
}

Email address:

oliyadsorizen@gmail.com (O. Sori)

${ }^{*}$ Corresponding author

To cite this article:

Oliyad Sori, Hika Wana. Profitability and Value Chain Assessment of Groundnut in Digga District of East Wollega Zone, Oromia National Regional State, Ethiopia. Agriculture, Forestry and Fisheries. Vol. 8, No. 4, 2019, pp. 81-88. doi: 10.11648/j.aff.20190804.11

Received: July 16, 2019; Accepted: August 15, 2019; Published: August 30, 2019

\begin{abstract}
Marketing inefficiencies and low coordination of groundnut value chain are the main problems though Digga district is potential in groundnut production. The study was conducted to analyze the profitability and value chain assessment of groundnut in Digga district of Oromia region, Ethiopia. More specifically, the study identified value chain actors, their respective roles, maps the value chain, and assesses the performance of groundnut production in the area. Primary data were collected through a survey using pre-tested semi-structured questionnaire and through key informant interview using checklists and generated from randomly sampled 123 groundnut producers, 28 traders and 25 consumers. The major actors of groundnut value chain were: input suppliers, producers, traders, processors and consumers. Two-stage sampling procedure was employed to draw sample of groundnut producers. Digga districtwas selected purposively based on the potential it has for groundnut production in the zone. In the first stage, from kebeles which produce groundnut, 4 kebeles were randomly selected. In the second stage, 123 samples of household heads were randomly selected from total groundnut producers in the district and the sample households were drawn randomly from each kebele based on probability proportional to size sampling techniques. Producers' highest gross marketing margin was $86.12 \%$ in channel III and highest total gross margin is $19.93 \%$ in channel IV while $13.88 \%$ is the lowest total gross margin in channel III. Cost incurred in groundnut production was 6588 Birr per Hectare and the gross income obtained from groundnut production was 9,600 Birr per Hectare and net income of the product was 3012 Birr per Hectare which shows groundnut production in Digga district is profitable. Opportunities and constraints of groundnut profitability and value chain were identified at each stage of value chain like input supply, production, processing, marketing and consumption of groundnut. The study recommended that farm machineries, improved seed of groundnut, market facilities and market outlets should be provided for farmers for insuring larger production and selling thereby to enhance profit of groundnut production in the study area.
\end{abstract}

Keywords: Groundnut, Profitability, Gross Margin, Digga

\section{Introduction}

With regard to adding value to agricultural products, Ethiopia has set Growth and Transformation Plan (GTP) and ensured agricultural input supply and strengthens agricultural extension services to increase agricultural productivity and commercialization. As a result, agriculture continued to be a source of growth and poverty reduction [18]. Agriculture stabilizes farm incomes, revives primary agriculture and rural economy when it becomes value added. Market-drivers are the fundamental cause for moving agriculture to be value added. Value-added activities are born from the necessity to adapt to the wide-ranging changes affecting the agriculture and agri-food industry [1]. Markets are prerequisites for enhancing agriculture-based economic growth and increasing rural income in the medium term particularly for the rural poor households [2].

Groundnut (Arachis hypogaea) is an edible seed of a 
legume plant and it is the six most important oilseed crops in the world [9] while it is the second important lowland oilseed of warm climate next to sesame in Ethiopia [6]. Similarly, it is one of the five among widely cultivated oilseed crops in Ethiopia [12].

The lowland areas of Ethiopia have considerable potential for increased oil crop production including groundnut. Groundnut is mainly grown in Oromia National Regional State (particularly in East Harerghe, West Harerghe, East Wollega, West Wollega, Horoguduru Wollega, Kelem Wollega, Ilubabor zones), Amhara National Regional State, Benishanul Gumuz National Regional State (Metekel, Asosa, Kemashi, Mao Komo zones), Southern Nations Nationalities and Peoples' Region (South Omo, KontoSpecial Wereda) and Gambela National Regional State and Dire Dawa [5]. According to the study [5] report on area and production of crops, groundnut was produced on $74,861.37$ hectares of land in the $2016 / 17$ cropping season leading to a total production of well over $129,636.418$ tones with an average national yield of 1.732 tones.

Groundnut is a nutritious food which serves as a source of food through securing food security of smallholder farmers in developing countries. It is a source of income for small scale farmers and brought foreign exchange earnings through export for Ethiopia [17, 11]. According to the paper [10], the prices for oilseeds and oilseed prices trended to be increased. This provides especial benefit for oilseed growing potential countries like Ethiopia. Exports of oilseeds from Ethiopia are expanding and total exports are performing better in the growing world market [16].

Global demand for groundnut in Ethiopia appears to secure due to consumption of oilseeds in Europe skyrocketed and they import oilseed in larger quantity and process it to edible oil. The various usage potential of oilseeds makes them a valuable commodity in Europe, especially for the food industry, but also for cosmetics and industrial purposes. Moreover, Europeans and North-Americans have an increased craving for quality foods, super foods and the like, in which group oilseed products invariably seem to be categorized [19].

The study [20] analyzed profitability of groundnut production in northern part of Taraba state, Nigeria by using budgetary-techniques and identified that total cost of farming (like average variable cost, depreciation of fixed cost) is less than total revenue of groundnut production which implied that profitability of groundnut production Taraba state. According to [3], groundnut production and market business are feasible but it needs better technologies to improve its economic value. It is also feasible crop to produce and use for household consumption and income generation.

Groundnut production in Ethiopia is found to be constrained by several biotic and abiotic factors like critical moisture stress especially during flowering and after, lack of improved varieties, inappropriate production and post-harvest practices, diseases affecting both above and underground parts of the plant and aflatoxin which affect the produce in the field and at various levels from harvest to market [4].
But, aflatoxin contamination of groundnut could be minimized through various agronomic and seed handling practices [8].

The research [14] conducted groundnut value chain in Babile district, eastern Ethiopia and identifiedthat groundnut market information is limited due to the traditional nature of the value chain, lack of co-ordination among smallholder farmers and rural-based traders, lack of access to finance and limited business skill, low quality and an absence of quality control at all market levels, lack of knowledge on the causes and risks of aflatoxin contamination and prices are determined by market actors, but information and power relationships are not equal along the market chain. The poorest groups, producers and roasted groundnut retailers shared unfair profit distribution compared to other actors; mainly associated with lower bargaining power and shortage of working capital which are factors that hinder groundnut value chain [13].

Different activities of the value chain stages are not coordinated to each other to create effective and efficient groundnut value chain in the district. Although the contributions of groundnut crop to secure income and alleviating poverty is substantial, limited attention has been given to groundnut research and development. Lack of coordination among smallholder farmers and rural-based traders, post-harvest management (such as storage), poor buyers' preference back flow from end consumers to producers, determination of prices by market actors, low quality and absence of quality control on production of the product and on the processing levels are the essential problems in the country and particularly in the district. Prices are determined by market actors, but information and power relationships are not equal along the market chain; farmers have weak negotiating power in the chain, and the failure of the co-operative has prevented farmers from building countervailing power.

By taking these problems into consideration, this study assessed groundnut profitability and value chain in Digga district by identifying groundnut value chain actors, their respective roles and sketch value chain map of groundnut, governance of value chain estimating and the cost and returns associated with groundnut production.

\section{Methods}

\subsection{Description of the Study Area}

The study was conducted in Digga district, Oromia National Regional State. The Woreda is located at about 346 $\mathrm{km}$ away from Addis Ababa and $15 \mathrm{~km}$ from Nekemte town to the West. The area shares boundaries with West Wollega Zone in the West, Guto Gida district in the East, Sasiga in the South and Leka Dulecha in the North. The study area is classified into middle altitude ranges 2100-2342 m.a.s.l and low land ranges 1200-2100 m.a.s.l. based on agro-climatical conditions. From these total land area middle altitude occupy $42 \%$ low land occupy $58 \%$. Diga district is general located 
among the high land areas of the country where the rainfall varies from 1376- $2037 \mathrm{~mm}$, and the annual mean temperature varies from 14.60 to 30.40 Celsius. The total population of the district is 106,664 while 62513 are women and 44,351 are men. The total area of the district is estimated at 40788 hectares. This total land is allocated to arable land, grazing land, forest land, bushes and shrubs, construction and others The district comprises both lowland (60\%) and midland (40\%) agro- ecologies. The main crops grown in the studyareaare; Teff (Eragrostistef) Fingermillet, Maize (Zea mays.L), Noug (Guizotia abyssinica), Faba bean (Vicia faba), maize, groundnut and sesame [7].

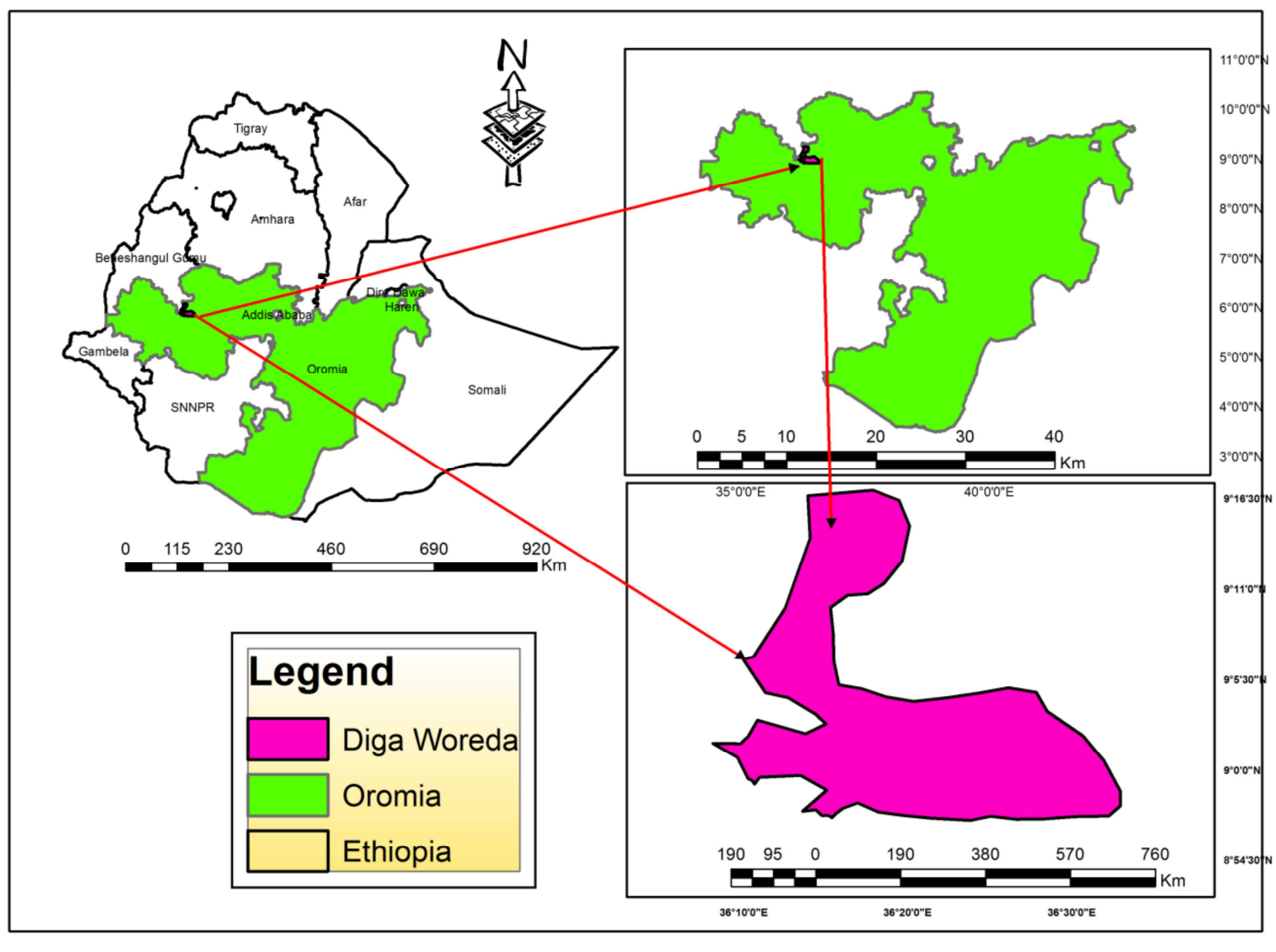

Source: Adapted from Ethiopia map

Figure 1. Geographical location of the study area.

\subsection{Types and Sources of Data}

Both qualitative and quantitative data were collected from primary and secondary data sources. Primary data were collected from sample farm households using pre-tested semi-structured interview schedule and observations. Besides, relevant secondary data sources were from Digga district Bureau of Agriculture, Central Statistical Authority (CSA), published and unpublished reports, and websites were used in addition the survey data.

\subsection{Sampling Techniques and Sample Size}

A two-stage sampling technique was used to select representative groundnut producers from the study area. Digga district was selected purposively based on the potential it has for groundnut production in the zone. In the first stage, from kebeles which produce groundnut, 4 kebeles were randomly selected. In the second stage, 123 samples of household heads were randomly selected from total groundnut producers in the district and the sample households were drawn randomly from each kebele based on probability proportional to size sampling techniques. Sample size was determined by [21] formula at $9 \%$ of significance level.

$$
\mathrm{n}=\frac{\mathrm{N}}{1+\mathrm{N}(\mathrm{e})^{2}} \mathrm{n}=\frac{15867}{1+15867(0.09)^{2}} \sim 123
$$

Where $\mathrm{n}=$ sample size, $\mathrm{N}=$ population size, $\mathrm{e}=$ level of precision $(9 \%)$

Table 1. Sample distribution of household in selected kebeles.

\begin{tabular}{llll}
\hline No. & Kebeles & $\begin{array}{l}\text { Total number of } \\
\text { groundnut producers in } \\
\text { each kebele }\end{array}$ & $\begin{array}{l}\text { Number of } \\
\text { sampledhouseholds } \\
\text { in each kebele }\end{array}$ \\
\hline \multirow{2}{*}{1} & Arjo Qonan & 662 & 33 \\
2 & Bula & 739 & 37 \\
3 & Bacbac & 454 & 23 \\
4 & Mada Jalala & 587 & 30 \\
& Dimtu & 2442 & 123 \\
\hline
\end{tabular}

Source: Digga district bureau of agriculture, 2016 


\subsection{Methods of Data Analysis}

\subsubsection{Descriptive Statistics}

Descriptive statistics employed were percentages, frequencies, means, maximum, minimum, ranges, and standard deviations in the process of describing households' characteristics.

\subsubsection{Profitability Analysis}

Both variable and fixed costs were considered for computing total cost of groundnut production. Opportunity costs of market wages and rental values were used to estimate value of family labors and land, respectively. In short, groundnut profitability analysis was calculated depending on gross revenue $(\mathrm{Birr} / \mathrm{Ha})$ and total cost (Birr/Ha). So, it is given as:

$$
\begin{aligned}
& \mathrm{NI}=\mathrm{GR}-\mathrm{TC} \\
& \mathrm{TC}=\mathrm{TVC}+\mathrm{TFC} \\
& \text { Where: } \\
& \mathrm{NI}=\text { Net income }(\mathrm{ETB} / \mathrm{Ha}) \\
& \mathrm{TC}=\text { Total cost }(\mathrm{Birr} / \mathrm{Ha}) \\
& \mathrm{GR}=\text { Gross revenue }(\mathrm{Birr} / \mathrm{Ha}) \\
& \mathrm{TVC}=\text { Total variable cost }(\mathrm{Birr} / \mathrm{Ha}) \\
& \mathrm{TFC}=\text { Total fixed cost }(\mathrm{Birr} / \mathrm{Ha})
\end{aligned}
$$

\section{Result and Discussion}

\subsection{Characteristics of Sampled Farm Households}

The characteristics of households in the study area indicated that the average age of total sample households was about 40.77 years. Out of total household heads interviewed, $26.02 \%$ were female headed households while $73.98 \%$ were male headed households. About $30.08 \%$ of the sampled

\begin{tabular}{|c|c|c|c|c|}
\hline Variable & Category & \multicolumn{2}{|r|}{ Frequency } & Percent \\
\hline \multirow{3}{*}{$\begin{array}{l}\text { Sex of household } \\
\text { heads }\end{array}$} & Male & \multicolumn{2}{|r|}{91} & 73.98 \\
\hline & Female & \multicolumn{2}{|c|}{32} & 26.02 \\
\hline & Illiterate & \multicolumn{2}{|c|}{37} & 30.08 \\
\hline \multirow{4}{*}{$\begin{array}{l}\text { Education of } \\
\text { household heads }\end{array}$} & Primary & & 59 & 47.97 \\
\hline & Secondary & \multicolumn{2}{|c|}{22} & 17.89 \\
\hline & Certificate & \multicolumn{2}{|c|}{5} & 4.07 \\
\hline & Mean & SD & Mini & Maximum \\
\hline Age & 40.77 & 9.02 & 22 & 71 \\
\hline Family size & 5.59 & 1.87 & 2 & 10 \\
\hline Farming experience & 6.80 & 2.50 & 2 & 13 \\
\hline
\end{tabular}
household heads were illiterate. However, $47.79 \%$ and $17.89 \%$ attended primary school and secondary school, respectively, whereas the smallest proportion $(4.07 \%)$ are certificate holders and above. Similarly, in the study area family size of the total sample households ranges from 2 to 10 persons with 6 average family sizes (Table 2).

Table 2. Characteristics of sample households.

Source: Own survey result, 2016

Among the households of the study area, 52.03\% are membership to their kebele's cooperatives. Out of the total sampled households of groundnut producers about $71.54 \%$ had access to extension service in 2016 production season. Only $56.10 \%$ of sampled households had access to credit in Digga district. About $64.23 \%$ of sampled households had access to market information from different sources (Table 3).

Table 3. Access to services of sampled households.

\begin{tabular}{llll}
\hline Variables & Response & Frequency & Percent \\
\hline \multirow{2}{*}{ Extension service } & Yes & 88 & 71.54 \\
& No & 35 & 28.46 \\
Credit & Yes & 69 & 56.10 \\
Market information & No & 54 & 43.90 \\
& Yes & 79 & 64.23 \\
Own transport & No & 44 & 35.77 \\
Membership to & Yes & 79 & 64.23 \\
cooperatives & No & 44 & 35.77 \\
\hline
\end{tabular}

Source: Own survey result, 2016

The type of information provided were market place information (7.59), price information (11.39\%), buyers' information (17.72\%) and (63.29\%) is combinations of these and other types of information provided (Table 4).

Table 4. Producers'type of market information.

\begin{tabular}{lll}
\hline Type of market information & Frequency & Percent \\
\hline Market place & 9 & 7.59 \\
Price information & 6 & 11.39 \\
Buyers' information & 14 & 17.72 \\
Price information and market place & 21 & 26.58 \\
information & 29 & 36.71 \\
Price, place and buyers' information & 79 & 100 \\
Total & & \\
\hline
\end{tabular}

Source: Own survey result, 2016

\subsection{Mapping of Groundnut Value Chain}

Mapping a value chain facilitates a clear understanding of the sequence of activities and the key actors and relationships involved in the value chain. Mapping of value chain functions is considered to show the relationships and integrations of the processes and activities performed along the value chain.

Inputs suppliers: Any activity requires an input to be transformed to a given product. Agricultural value chain begins at the input supply level. Input such as seed is mostly supplied from fellow farmers and according to the result there were no many cooperatives, bureau of agriculture, agricultural research institutes which provide improved groundnut seed for producers. Instead of pesticides for weeds, producers use manual weeding which wastes time and requires labors; and farm implements are rarely supplied by cooperatives, bureau of agriculture, Uke Research and Demonstration Station, traders, and informal farmers.

Farmers: Farmers play a great role in groundnut value chain in the study area. They mostly produce it for selling to different channels around production area and they consume it in their home a little amount. Farmers decide, what input to use, when to saw seed and harvest, how much to consume, 
and how much to sell by considering the available resources. They perform activities from farm inputs preparation to post harvest handling and marketing. The major value chain functions that groundnut farmers perform include land preparation, sawing seed, fertilization, weeding, pesticides, harvesting and post-harvest handling and marketing.
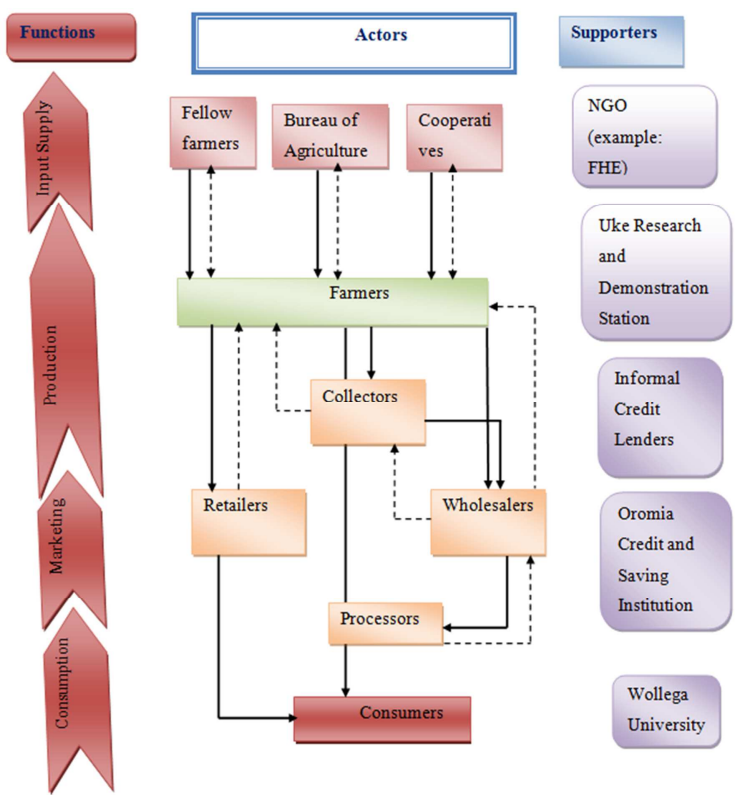

Figure 2. Groundnut value chain map.

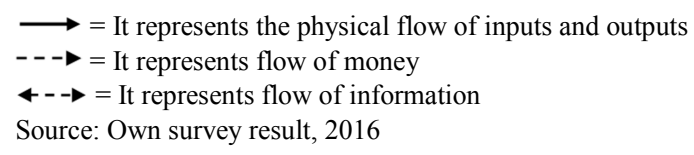

Collectors: They collect groundnut from the farmers and sell to wholesalers. Mostly they face the problem of lack of finance since they purchase groundnut by taking money from wholesalers and other traders or by taking loan from different sources. Mostly, collectors purchase groundnut at lower price than other traders and there is a time in which farmers are forced to sell their produce to collectors in larger quantities. In addition, collectors assemble and transport groundnut from smallholder farmers, using pack animals and small trucks for sale to markets of kebeles, district and zone.

Wholesalers: With regard to other traders, producers of the study area have an opportunity to sell their produce directly to wholesalers in their surroundings. Wholesalers are traders that buy groundnut from collectors and also directly from farmers and resale to processors in Addis Ababa and they sometimes with better financial and information capacity than other groundnut traders of study area. Similarly, this outlet own or rent storage and store for a long or short time depending on the situation of the market. Even though, their function is not well structured and well-functioning, there are some wholesalers who have license to collect the product from other actors to distribute it to processors in Addis Ababa. Still, the product does not move to other countries passing through the country for export by the groundnut actors.

Retailers: Retailers are key actors in groundnut value chain within and outside the study area mostly from district's surroundings to purchase groundnut and to supply to zonal market. Roasted groundnut provides significant livelihood source for many poor in the zone. Retailers are the last link between producers and consumers among other actors of groundnut in the area though producers directly sell produce to consumers. Retailers buy the product from producers and sell it to consumers who are in Nekemt town or to residents of other districts of the zone.

Brokers: Some wholesalers use brokers for facilitating transaction by compelling wholesalers to the produce and to seek good and quality product for processors in Addis Ababa. Among groundnut actors of the study area, brokers are used only in between wholesalers and processors. Brokers sometimes created problems like wrong price information, cheating scale to wholesalers and high product price to processors. In contrast to this, they show advantage like saving time, methods of easily getting purchasers and sellers to both wholesalers and processors.

Groundnut oil processors: Nut oil processors are largely small-scale processors and are mostly found in Addis Ababa. By mixing with noug, they process crude nut oil. Besides oil processing activities, they also retail the oil. Unless groundnut from the study area moved by wholesalers to Addis Ababa to be processed to oil, no producers would sell their produce directly to processors in Addis Ababa or other areas. Quantity of groundnut transported for processing was not in larger quantity and of poor quality since there are small amount of the product and no too many traders engaged in trading and selling groundnut to processors in the study area. The only wholesaler market outlet sell groundnut to processors in Addis Ababa by purchasing it directly from both producers and collectors.

Consumers: Consumers are final purchasers of groundnut mostly from retailers for consumption purpose. They can also purchase directly from farmers that sell roasted/raw groundnut roasting or without roasting which is either with pod or unshelled. Most of the consumers prefer roasted groundnut and consume it individually or in group especially in restaurants to use it to complement with drinks while others purchase unroasted groundnut for home consumption.

\subsection{Gross Margin Analysis}

Costs and returns of groundnut production were determined on a per hectare basis. Costs like fixed and variable cost were an expense which incurred for groundnut production. Cost estimation was figured out for groundnut with pod. They sell the product by packing with sack which could equal to $33.3 \mathrm{Kg}$ when the pod is removed. But, revenue was computed by considering the money obtained by selling groundnut. The selling price of groundnut by producers is by considering three quintal of shelled groundnut equal to one quintal of unshelled groundnut.

Table 5 indicated the benefit cost analysis of groundnut production in Digga district of 2016 production season. Accordingly, the total fixed cost and variable costs incurred for groundnut production were calculated by Birr per 
Hectare. The growth income and net income were also calculated by Birr per Hectare. Accordingly, cost incurred in groundnut production was 6588 Birr per Hectare and the gross income obtained from groundnut production was 9,600 Birr per Hectare and net income of the product was 3012 Birr. Computation of total costs and gross income in the study area implies that groundnut production is profitable. The result is consistent with the findings of [20] and [12], who stated groundnut production, is profitable enterprise inTaraba state and eastern Hararghe zone, respectively.

Table 5. Cost and return of groundnut production.

\begin{tabular}{lll}
\hline Variable & Birr/ha & Percentage \\
\hline Variable cost & & \\
Seed & 760 & 11.53 \\
Fertilizer & 551 & 8.36 \\
Draft power & 592 & 8.98 \\
Labor (weeding, harvesting) & 2343 & 35.56 \\
Total variable cost & 4246 & 64.45 \\
Fixed costs & & \\
Land & 1142 & 17.33 \\
Depreciation & 252 & 3.82 \\
Interest & 169 & 2.56 \\
Total fixed cost & 1563 & 23.72 \\
Other costs & & \\
Cleaning & 189 & 2.86 \\
Store & 197 & 2.99 \\
Packaging & 184 & 2.79 \\
Transporting & 209 & 3.17 \\
Total other costs & 779 & 11.82 \\
Total cost & 6,588 & 100.00 \\
Gross income & 9,600 & \\
Net income & 3,012 & \\
\hline
\end{tabular}

Source: Own computation from survey result, 2016

\subsection{Groundnut Margin Analysis}

The researcher [15] argued, when there are several participants in the marketing chain, the margin is calculated by finding the price variations at different segments and then comparing them with the final price to the consumer. The consumer price is then the base or the common denominator for all marketing margins. Margin determination should be conducted by taking in consideration of price received or selling price. The following table 6 below clearly depicted that differences between the total income from groundnut trading and the costs incurred in the process of groundnut trading which gives the marketing profit of each actor namely producers, collectors, wholesalers and retailers. The result showed that farmers market profit was the highest when they direct sell to consumers in channel I which is 682 birr/qt, second highest profit when they sell to retailers of channel IV which is 648 birr/qt, also they got less profit when they sell to wholesalers (channel III) which was 626 birr/qt and at the last farmers got the least profit by selling to collectors (channel II) which was 593 birr/qt. This implies farmers get more profit if they sell groundnut product directly to consumers and retailers. The maximum farmers' share (GMMp) is highest $(86.12 \%)$ from channel III and lowest $(80.06 \%)$ in channel IV. From traders, retailers shared the highest profit 191 birr/qt when they made direct purchase from producers in channel IV and they sell to consumers. Wholesalers gained the second highest profit 78 birr/qt from channel III, when they buy directly from producers and sell to processors in Addis Ababa. Groundnut collectors made a profit of $60 \mathrm{birr} / \mathrm{qt}$ from channel II. This implies that retailers and wholesalers received the highest profit from groundnut marketed in the study area while collectors took the smallest profit shares from groundnut value chain though they purchase larger quantities from producers next to wholesalers.

Table 6. Groundnut margin analysis.

\begin{tabular}{|c|c|c|c|c|c|}
\hline \multirow[t]{2}{*}{ Agents } & \multicolumn{5}{|c|}{ Groundnut marketing channels } \\
\hline & & $\mathrm{I}$ & II & III & IV \\
\hline \multirow{5}{*}{ Producers } & Production costs & 387.23 & 387.23 & 387.23 & 387.23 \\
\hline & Marketing costs & 73 & 62 & 69 & 72 \\
\hline & Selling price & 1300 & 1200 & 1240 & 1265 \\
\hline & Profit & 839.77 & 750.77 & 783.77 & 805.77 \\
\hline & GMMp (\%) & 100 & 83.33 & 86.12 & 80.06 \\
\hline \multirow{5}{*}{ Collector } & Purchase price & & 1200 & & \\
\hline & Marketing costs & & 40 & & \\
\hline & Selling price & & 1300 & & \\
\hline & Profit & & 60 & & \\
\hline & GMM & & 6.94 & & \\
\hline \multirow{5}{*}{ Wholesaler } & Purchase price & & 1300 & 1240 & \\
\hline & Marketing costs & & 122 & 122 & \\
\hline & Selling price & & 1440 & 1440 & \\
\hline & Profit & & 18 & 78 & \\
\hline & GMM & & 9.72 & 13.88 & \\
\hline \multirow{6}{*}{ Retailer } & Purchase price & & & & 1265 \\
\hline & Marketing costs & & & & 124 \\
\hline & Selling price & & & & 1580 \\
\hline & Profit & & & & 191 \\
\hline & GMM & & & & 19.93 \\
\hline & TGMM (\%) & 0 & 16.67 & 13.88 & 19.93 \\
\hline
\end{tabular}

Source: Own survey result, 2016

\subsection{Value Chain Governance}

Value chain governance is the relationships among the buyers, sellers, service providers and regulatory institutions that operate within or influence the range of activities required to bring a product or service from inception to its end use.

With regard to the stability of groundnut price, there is a time supplying product abundantly and scarcely. The price by which the product is sold and the time farmers supply their product in larger quantity does not match together. Some respondents were enforced to immediately sell the product after harvest to pay for different payments like government tax. Traders, especially wholesalers store groundnut for longer time than other traders and producers.

The price setting between producers and traders, traders and traders mostly done through negotiation and some traders put their power on producers of setting price. And also, traders complain for the existence of non-licensed traders and lower quantity supply of groundnut of the study area. When they purchase groundnut from producers, traders give price depending on the quality of the produce.

As the result of the study identified, wholesalers are the main groundnut value chain governors through coordination of product flow and suppliers. Wholesalers have sufficient 
information about the supply of groundnut and which direction it flows along the marketing channels and sell it to processors in Addis Ababa. Wholesalers are well networked with each other's as well as with brokers but informally. These traders exchange information on groundnut prices, local supply situation and the prospects of harvest in their area. Generally, the governance structure in the study area was characterized by low coordination among the value chain actors in information exchange and knowledge transfer and low involvement in improving trust in between producers, traders and service providers in the study area. This resulted in producers' low profit sharing with the existing groundnut actors in Digga district.

\subsection{Challenges of Groundnut Chain Actors}

\subsubsection{Production and Marketing Constraints of Groundnut Producers}

The major constraints of groundnut value chain actors were seen mostly on the production, trading and consumption levels.

Production constraints faced by farmers are the absence of good quality seed, limited knowledge and experience on the proper cultivation and plantation, harvesting and postharvest handling activities; farmers' lack of long year farming experience (which was 6.8 years on average), lack of storage, inadequate credit service and market information. Concerning input supply, the finding of the study shows that there are no formal institutions which supply improved groundnut seed for the farmers. Farmers purchase seed from other farmers by selecting good seed by their experience which could negatively affect their return. Service providers of the study area like credit institutions could not provide sufficient services for the producers.

Farmers bear the problems of handling techniques after harvest, leading to significant losses, which affect the produce to be affected by aflatoxin. Aflatoxin affect the produce both before and after harvest and households suffer this problem since disease is not managed. Furthermore, though $73.98 \%$ sampled households store their product after harvesting, they do not have good storage facilities available at the production, and this forces them to face the problem of supplying good quality products to the market. Producers lack the locally made machine which is used to remove pods and so they pack their produces using sacks. Those who want to sale to wholesalers and others employ the machine daily by payment and remove pod.

On the side of groundnut marketing, unfairness when weighting the groundnut, lack of marketing information and fluctuation of prices were the main problems identified by respondents. With regard to marketing constraints, about $99.2 \%$ of sampled farmers faced ranked marketing problems. Accordingly, among the ranked problems of producers' marketing problems, $78.05 \%$ highly faced severe lack of market while the remaining $21.95 \%$ are with less severe lack of market. Around $70.73 \%$ of the total producers are highly affected by low price of groundnut while the remaining is less affected (Table 7). By the storage problems, there were no such high severe problems since producers were not storing their produce for a long period of time. Households lack small processing equipment in their home to process the produce. Absence of adequate value chain finance for facilitating production and marketing of groundnut is also the core problem.

Table 7. Households' marketing constraints.

\begin{tabular}{lll}
\hline \multirow{2}{*}{ Marketing Constraints } & Effect & \\
\cline { 2 - 3 } & $\begin{array}{l}\text { Most severe } \\
\text { (in percent) }\end{array}$ & $\begin{array}{l}\text { Second severe } \\
\text { (in percent) }\end{array}$ \\
\hline Lack of market & 78.05 & 21.95 \\
Low price & 70.73 & 29.27 \\
Lack of storage & 34.15 & 65.85 \\
\hline
\end{tabular}

Source: Own survey result, 2016

\subsubsection{Marketing Constraints of Traders}

There is trading challenges recognized along traders in which larger quantities are not supplied for them from either producers or other traders. Most of the traders, lack trade license which could make activities of traders' incompetent. Traders of the study area could not get higher profit as a result of absence of exporting groundnut. Wholesaler traders specifically complained that when groundnut is collected from farmers, it is of low quality. Because of lack of proper storage facility and limited knowledge of traders about groundnut, the quality of the produce continues to deteriorate when stored for a relatively longer period of time in the hands of traders. In addition, trader respondents blamed lack of capital as the major limitation in their activities. Given the fact, traders involved in groundnut trading in Digga district started their trading business with low capital generated from their own, loan and gift. Lack of regular supply of groundnut either from producers or other traders were mentioned as a serious problem for traders. For processors on the other hand, they responded that low quality, low volume, and absence of groundnut supply on time and lack of capital are the existing constraints. Similarly, consumers faced problems of low quality of groundnut supplied from producers and retailers.

\section{Conclusions}

Groundnut plays a great role to improve the income of farmers in the study area. The study was under taken with the aim of analyzing profitability of groundnut production and assessment of groundnut value chain. Different groundnut value chain actors like producers, collectors, wholesalers, retailers and consumers were identified. Value chain supporters the product include research centers, Wollega university, districts' financial institutions, non-government organizations (FHE), and Oromia saving and credit institution. Input such as seed is mostly supplied from fellow farmers and according to the result there were no many cooperatives, BoA, agricultural research institutes which provide improved groundnut seed for producers. Farmers sell the product to collector, wholesaler, retailers and consumer market channels. The result showed that farmers market profit was the highest when they direct sell to consumers in channel I which is 682 birr/qt and they get the 
least profit by selling to collectors (channel II) which was 593 birr/qt. The maximum farmers' share (GMMp) is highest $(86.12 \%)$ from channel III and lowest $(80.06 \%)$ in channel IV. The result of the study revealed that the production of groundnut in the study area is profitable venture. Similarly, opportunities and constraints of groundnut profitability and value chain were identified at input supply, production, marketing and consumption of groundnut.

\section{Recommendations}

The findings of the study recommend that, supply of improved seed for further production of groundnut since farmers are using local seed of groundnut, providing technologies especially as groundnut is exposed for disease called aflatoxin it must be manageable, increasing accessibilities and linkages of the market thereby to improve farmers market information, setting legal agreement for traders to have trading license, providing value adding materials like storage areas, packing materials, machine which is used to remove pods, strengthening the awareness of farmers on price determination, organizing farmers on how they become coordinated and play their role to add value to the product to get larger profit.

\section{Authors' Contribution}

Authors collected both primary and secondary data, analyzed, interpreted, wrote draft and revised manuscript and approved it.

\section{Conflict of Interest}

We have no conflict of interest.

\section{Acknowledgements}

We thank God from our heart that saved us from all sins by the blood of his only SON and helped us to conduct this research.

\section{Funding}

This research is financially supported by Ethiopian ministry of education.

\section{References}

[1] AAFC (Canada, Agriculture and Agri-Food Canada). 2004. Value-added Agriculture in Canada. Report of the Standing Senate Committee on Agriculture and Forestry.

[2] Adeoti, A., Issack, I., Oluwatayo, B, Rahem, O. S. 2014. Determinants of Market Participation among Maize Producers in Oyo State, Nigeria. Journal of Economics, Management and Trade, 4 (7): 1115-1127.

[3] Addisu G, Erimias T. 2017. Value Chain Assessment Study of
Groundnut in Northwestern Ethiopia. British Journal of Economics, Management and Trade, 16 (2): 1-15.

[4] Alemayehu C, Berhanu A, Mulugeta Taye, Abdi M, Tameru A, Helge, S. 2014. Opportunities and Constraints of Groundnut Production in Selected Drylands of Ethiopia. Drylands Coordination Group, 74.

[5] CSA (Central Statistical Agency. 2017. Reports on Area and Production of Crops (Private Peasant Holdings, Meher Season). Addis Ababa, Ethiopia.

[6] Dawit A, Samuel, M. nd. Groundnut Production and Marketing Intervention to Empower the Value Chain. ICRISAT.

[7] DDAO (Digga DistrictAgricultural Office). 2016. Annual Report of the district. Digga, East Wollega Zone, Ethiopia.

[8] Ephrem, G.2015. Aflatoxin Contamination in Groundnut (Arachis hypogaea L.) Caused by Aspergillus Species in Ethiopia. Journal of Applied \& Environmental Microbiology, 3 (1): 11-19.

[9] FAOSTAT (Food and Agriculture Organization of the United Nations). 2015. Groundnut world production.

[10] FAO (Food and Agriculture Organization). 2016. Trade and Markets Division of Oil Crops. Food Outlook. Rome, Italy, 2016. Food and Agriculture Organization of the United State.

[11] Geleta T, Purshotum, K. S., Wijnand, J. S, Tana T. 2007. Integrated management of Groundnut Root Rot Using Seed Quality and Treatment. International Journal of Pest Management, 53 (1): 53-57.

[12] Gezahagn K. 2013. Economics of Groundnut Production in East Hararghe Zone of Oromia Regional State, Ethiopia. Science, Technology and Arts Research Journal, 2 (2): 135-139.

[13] Gezahagn K. 2010. Value Chain Analysis of Groundnut in Eastern Ethiopia. M.Sc. Thesis. Haramaya University, Haramaya, Ethiopia.

[14] Jemal Y, Chisholm, N. 2015. The Groundnut Value Chain in Babile District, Eastern Ethiopia. An AgriDiet Research Brief.

[15] Mendoza G. 1995. A premier on marketing channel and margins. Lyme Rimer Publishers Inc., USA.

[16] NBE (National Bank of Ethiopia). 2015. National Bank of Ethipia. Annual Report. 2014/15. Addis Ababa, Ethiopia.

[17] Nedumaran S, Abinaya P, Jyosthnaa P, Shraavya B, Parthasarathy R, Cynthia B. 2015. Grain Legumes Production, Consumption and Trade Trends in Developing Countries. ICRISAT, No. 60.

[18] NPL (National Plan Commission). 2015. The First Growth and Transformation Plan (GTP I). Addis Ababa, Ethiopia.

[19] Ruters T, Boere A, Willems D, Dawit K, Dolfen W. 2015. Business Opportunity Report: Oilseeds and Pulses. Ministry of Economic Affairs and Ministry of Foreign Affairs. Den Haag. The Netherlands.

[20] Taphee G. B, Jongur A. A. U, Dengle Y. G, Ephraim I. J. 2015. Analysis of Profitability of Groundnut Production in Northern Part of Taraba State, Nigeria. International Journal of Computer Application, 125 (1): 0975-8887.

[21] Yamane T. 1967. Statistics: An Introductory Analysis, 2nd Ed. New York: Harper and Row. 